J. Mark Ramseyer Harvard Law School Cambridge, MA 02138 ramseyer@law.harvard.edu

Eric B. Rasmusen Kelley School of Business Indiana University Bloomington, IN 47405 erasmuse@indiana.edu

\title{
Are Americans More Litigious? Some Quantitative Evidence
}

\section{by}

\section{J. Mark Ramseyer \& Eric B. Rasmusen*}

Many observers suggest that American citizens sue more readily than citizens elsewhere, and that American judges shape society more powerfully than judges elsewhere. We examine the problems involved in exploring these questions quantitatively. The data themselves indicate that American law's notoriety does not result from how we handle routine disputes. Instead, it results from the peculiar and dysfunctional way American courts handle particular legal doctrines like class actions.

* Mitsubishi Professor of Japanese Legal Studies, Harvard Law School; Dan R. and Catherine M. Dalton Professor, Kelley School of Business, Indiana University. 


\section{Introduction}

Let's begin with some stories.

McDonald's Coffee. Stella Liebeck ordered coffee at a McDonald's drive-through and promptly spilled it on her lap. Because of her absorbent sweat pants, she suffered severe burns. She sued, and a jury awarded her $\$ 2.86$ million, cut by the judge to $\$ 650,000$. Eventually, Liebeck and McDonald's settled out of court. ${ }^{1}$

Spill, sue, go home with \$2.86 million. The courts-as-demented-slot-machines story shocked most readers, and the case's eventual settlement got buried in the newspapers' back pages. As odd as the bizarre verdict, however, was the positive press it earned among legal professionals. Predictably, the trade association for the plaintiffs' bar (formerly the American Trial Lawyers Association; now pleasantly renamed the American Association for Justice) celebrated the award as a victory for justice. More curiously, even prominent law professors found good things to say about \$2.86 million for a coffee spill. ${ }^{2}$

Chipotle's Wheelchair. Maurizio Antoninetti wheeled himself into a Chipotle Mexican Grill and complained about the service-line counters. Set at a height convenient for those who could walk, they were too high for Antonietti. The restaurant said it would happily show him the food in cups or at a private table, but Antonietti would have none of that. He sued. The Americans with Disabilities Act entitled him to "reasonable accommodation," he argued, and a special viewing at a special table was inferior. He wanted the full "Chipotle experience." For that, the franchise needed to install lower counters.

The $9^{\text {th }}$ Circuit found for Antonietti, and granted injunctive relief. The chain was required to install lower counters -- counters convenient for wheelchaired customers and inconvenient for everyone else. And because the District Court had awarded Antonietti only \$136,537 in attorney's fees, the Circuit Court remanded the case to give him more.

Since immigrating to the United States in 1990, Antoninetti had sued more than twenty businesses over service quality. Only once had he ever returned to an establishment, the Court acknowledged, but it declared that point irrelevant. The restaurant owed wheelchair customers lower counters whether Antoninetti would ever eat there again or not. ${ }^{3}$

${ }^{1}$ Liebeck v. McDonald's Restaurants, P.T.S., Inc., No. D-202 CV-93-02419, 1995 WL 360309 (Bernalillo County, N.M. Dist. Ct. August 18, 1994).

2 See Marc Galanter, “Oil Strike in Hell: Contemporary Legends about the Civil Justice System,” Arizona Law Review, 40 (1998) 717-52, at 731; Richard Lempert, "Why Do Juries Get a Bum Rap-Reflections on the Work of Valerie Hans," DePaul Law Review, 48 (1998-1999) 453, at 459; Arthur R. Miller, New York University Law Review 78 (2003) 982 at 987; William Haltom and Michael J. McCann, “Java Jive; Genealogy of a Juridical Icon,” pp. 183-226 of Distorting the Law: Politics, Media, and the Litigation Crisis, University of Chicago Press (2004).

3 Antoninetti v. Chipotle Mex. Grill, Inc., $9^{\text {th }}$ Circuit $08-55867$, http://www.ca9.uscourts.gov/opinions/view_subpage.php?pk_id=0000010681 (2010). 
Cigarettes. In the 1990’s, Mississippi plaintiffs' lawyer Richard "Dickie" Scruggs sued cigarette companies on behalf of 46 states. By convincing consumers that smoking was safe, he argued, the companies had increased the Medicaid bills that state governments had to pay. That anyone in the last half century really thought smoking safe was unclear. Rather clearer was that smoking, by killing its victims quickly and early, reduces -- rather than increases -- government health care and pension costs. ${ }^{4}$

But never mind such questions. Under the 1998 Tobacco Master Settlement Agreement, the companies agreed to restrict their marketing and lobbying and to pay \$246 billion dollars over 25 years (\$900 million to Scruggs's law firm). ${ }^{5}$ And the intellectual class cheered. The New York Times applauded the settlement and lamented only that the regulatory strictures were not harsher still. ${ }^{6}$

A reader might think Americans use litigation in place of legislation and regulation. He might think judges wield enormous and capricious power. He might think litigants unpredictably manipulate the power of the state by using (or abusing) a judicial branch immune from any democratic checks. He might also think that for American businesses, law is as important as commerce. Making a good product at low cost is all well and good, of course. But retaining a top-flight law firm to protect the firm's assets against those would judicially expropriate them would seem a sensible first priority.

If true, the need to protect one's firm from judicially sanctioned theft is a distinctively American exigency. It is not a story one hears about other wealthy democracies, common though it is in poorer countries. What is more, the intellectual impulse instinctively to defend these outcomes also seems uniquely American. Courts in other countries do issue bizarre opinions from time to time-. Idiocy knows no boundaries. But "tort reform" as a major policy issue is a peculiarly American debate.

We undertook this project to quantify the use of courts across countries. Quickly, however, we realized that we could not reliably measure what really matters. The theoretical problems lay in identifying measurable phenomena that accurately reflect the impact of courts. The empirical problems stemmed from the high aggregation level of the data available.

That data does indicate, however, that for routine contract, tort, and property disputes, courts in America perform about as well as in other wealthy countries. The notoriety of the U.S. legal system does not stem from these routine disputes. It stems instead from the abysmal performance of U.S. courts when they encounter certain highprofile disputes. Aggregate numbers are not informative about this kind of dysfunction, though much can be said about it, as we will do in the last part of this chapter.

II. Comparative Litigation Statistics:

A. Conclusion as Introduction:

${ }^{4}$ W. Kip Viscusi, “The Governmental Composition of the Insurance Costs of Smoking,” Journal of Law and Economics, 42, No. 2 (October 1999), pp. 575-610.

${ }^{5}$ Master Settlement Agreement, http://www.naag.org/backpages/naag/tobacco/msa/msapdf/MSA\%20with\%20Sig\%20Pages\%20and\%20Exhibits.pdf/file_view. For the history, see Wikipedia, Master Settlement

Agreement," http://en.wikipedia.org/wiki/Tobacco_Master_Settlement_Agreement (31 May 2010).

6 "Holes in the Tobacco Settlement," New York Times, June 27, 1997. http://www.nytimes.com/1997/06/27/opinion/holes-in-the-tobacco-settlement.html. 
1. The results. -- Table 1 shows a number of proxies for the use of the courts across six wealthy democracies. We will discuss them as a group first, and then review the proxies individually.

Note first that although each of the proxies plausibly measures court usage, the proxies do not correlate with each other very closely. The U.S. has about a quarter more suits per capita than does the U.K., but 3.3 times as many as Canada. It has fewer judges per capita than France, but four times as many as the U.K. It has 17 times as many lawyers per capita as Japan, but the same number as Australia. It has twice the motor vehicle insurance costs of Australia, but lower costs than Canada.

Table 1: Various Measures of Litigation

\begin{tabular}{|c|c|c|c|c|c|c|}
\hline & Australia & Canada & France & Japan & $\begin{array}{l}\text { U.K. } \\
\text { England }\end{array}$ & or USA \\
\hline $\begin{array}{l}\text { Suits filed } \\
\text { (per 100,000 } \\
\text { people) }\end{array}$ & 1,542 & 1,450 & 2,416 & 1,768 & 3,681 & 5,806 \\
\hline $\begin{array}{l}\text { Judges } \\
\text { (per } \\
\text { people) }\end{array}$ & 4.00 & 3.3 & 12.47 & 2.83 & 2.22 & 10.81 \\
\hline $\begin{array}{l}\text { Lawyers } \\
\text { (per } \quad 100,000 \\
\text { people) }\end{array}$ & 357 & 26 & 72 & 23 & 251 & 391 \\
\hline $\begin{array}{l}\text { Motor insurance } \\
\text { (\%GDP) }\end{array}$ & 0.81 & 1.35 & 0.93 & 0.72 & 0.93 & 1.45 \\
\hline $\begin{array}{l}\text { Motor insurance } \\
\text { (US\$ per car) }\end{array}$ & 664 & 1,574 & 786 & 754 & 927 & 1,464 \\
\hline $\begin{array}{l}\text { Cost of contract } \\
\text { action } \\
\text { (\% of value) }\end{array}$ & 20.7 & 22.3 & 17.4 & 22.7 & 23.4 & 14.4 \\
\hline
\end{tabular}

Sources: Various --- see later sections of this chapter.

Notes. Explanations of these numbers are important and are given later in the chapter. The top three rows are for England, and the bottom three for the United Kingdom, since Scotland and Northern Ireland have separate legal systems.

Note second that America is not special. From the stories that dominate the newspapers, our courts seems crazed. Yet most litigation involves nothing like those 
bizarre disputes and so they only lightly affect measures such as suits filed or the number of judges. Ordinary litigation involves car crashes and broken contracts. These disputes dominate the courts. All six countries use courts to resolve this kind of dispute, and the courts resolve them similarly, maintaining stable property rights and facilitating efficient investment. Indeed, a central reason these countries are wealthy is that their courts handle these routine disputes well.

2. Their significance. -- Table 1's level of aggregation tells us about what we might call "first-order law": the typical disputes over automobile accidents and contract claims. Countries differ in how well their courts handle these mundane disputes. Even among wealthy democracies some courts handle them more efficiently than others. But compared to developing economies even the least efficient does reasonably well. Despite the bewildering array of organizations and procedures, the end results are similar. ${ }^{7}$

American notoriety stems instead from what we might call "second-order law": coffee spills, ADA suits, and tobacco settlements. These cases generate controversy, make a few trial lawyers rich, and provoke relentless calls for reform. This law can profoundly affect social relations and the economy, but not because the cases are common or even because they transfer large amounts of money. Rather, the measurable, litigated, cases cause households and firms to take expensive precautions of little social value.

The U.S. is exceptional not in how it handles first-order law (the rest of this Section II), but in how it handles second-order law (Section III). In the typical accident or contract claim, U.S. courts do reasonably well. They may face somewhat more litigation than other rich democracies, but not much. In the second-order cases, however, the U.S. courts entertain claims that courts in other well-functioning economies would dismiss in short order. In the process, they necessarily create a drag on American business. As was said some time ago:

Increasingly, the civil justice system seems to be two different systems. One is a stable system that provides modest compensation for plaintiffs who claimed slight or moderate injuries in automobile and other accidents that have been the major source of litigation for 50 years. The second is an unstable system that provides continually increasing awards for claims for serious injuries in any type of lawsuit, and for all injuries, serious or not, in product liability, malpractice, street hazards and workplace accidents. ${ }^{8}$

B. Suits per capita:

1. Introduction. -- When someone claims that the U.S. is exceptionally "litigious," what evidence might he cite to support the claim? What might someone else cite to dispute it? What does such a claim even mean? To explore these questions, turn first to the number of civil suits filed.

${ }^{7}$ In this regard, the data has not improved since the articles of Marc Galanter in 1983 in the UCLA Law Review and Basil Markesinis in 1990 in the Cambridge Law Journal.

${ }^{8}$ M.A. Peterson 1986 (quoted in Markesinis (1990)): 
2. The United States. -- Although most litigation in the U.S. occurs in state (not federal) courts, data on state court litigation are maddeningly elusive. The court systems themselves differ widely. Some states use small-claims courts while others do not. Some states use subject-specific courts while others route all suits to a single court. Those states that do use the small-claims courts employ widely varying jurisdictional cutoffs. Faced with such disparate systems, the National Center for State Courts (the NCSC) does the best it can, but about 10 percent of the states return its surveys with only incomplete data. Another 10 percent report the wrong data.

Doing what it can with those surveys, the NCSC finds that plaintiffs filed 7.9 million suits in state courts of unified and general jurisdiction in 2006 and another 10.2 million suits in limited jurisdiction courts (e.g. small claims courts), a total caseload of 18 million. ${ }^{9}$

Additionally, plaintiffs filed 272,000 new civil suits in federal District Courts, including 34,000 contract claims, 4,000 real property claims, and 77,000 tort claims (15,000 of them relating to asbestos). The rest of the claims were statutory: 53,000 prisoner petitions, 32,000 civil rights cases, 19,000 labor law cases, 13,000 social security claims, and 11,000 intellectual property disputes. ${ }^{10}$

Within the state courts, case composition varies widely. In Kansas, 89\% were contract disputes and 5\% small claims, while in Wisconsin 16\% were contracts disputes and $64 \%$ small claims. Among seven states reporting detailed composition data, tort cases ranged from $1.5 \%$ to $8.0 \%$ of the total. (CSP-2007, p. 2). Small claims comprised 44 percent of incoming civil cases. General civil cases -- tort, contract, and real property cases not filed as small claims -- were 37 percent, most of them contract cases (Civil Caseloads, at 21).

The federal government surveyed state filings that went to trial (Langton and Cohen). The parties settled or abandoned $97 \%$ of cases in courts of general jurisdiction, though of the cases that did go to trial, $61 \%$ were torts. Consistent with the phenomenon of "the vanishing trial," ${ }^{11}$ in the nation's 75 most populous counties the number of general civil cases disposed of by trial declined 50\% from 1992 to 2005.

3. Japan. -- In 2008, disputants filed 2.3 million civil cases in the Japanese courts at all levels, ${ }^{12}$ a majority of them (1.4 million) in summary courts with jurisdiction over claims of less than 1.4 million yen (Courts Act, Sec. 32; in Aug. 2010, \$1.00 = 85 yen).

Many of these "cases" involved petitions for various orders in insolvency or other specialized proceedings. Of the 2.3 million newly filed cases, Japanese courts catalogued

${ }^{9}$ Shauna Strickland, et al., State Court Caseload Statistics, 2007: Supplement to Examining the Work of State Courts, 2007 tabs. 1, 2 (Williamsburg, VA.: National Center for State Courts, Bureau of Justice Statistics).

Tab. 3232007 data from U.S. Dept. Commerce, Statistical Abstract of the United States, 2010
(Washington, Http://www.census.gov/compendia/statab/2010edition.html.

${ }^{11}$ See Marc Galanter, “The Vanishing Trial: An Examination of Trials and Related Matters in Federal and State Courts,” Journal of Empirical Legal Studies, 1 (2004) 459-570.

12 Japanese court filing data from the Shiho tokei nempo, etc. 
only 828,000 as "litigation suits." And within the district (as opposed to summary) courts, only 222,000 involved "litigation suits."

Recent court statistics do not break down litigation by subject, but in 1994 the district courts heard 146,392 "litigation suit" claims: 35,220 involved loans and credit transactions, 33,447 real estate, and 6,360 traffic accidents (Tab. 23, Shiho tokei, 1994). In the summary courts, 195,240 of the 244,131 suits involved loans and credit transactions, 4,623 real estate, and 1,215 traffic accidents (id., at tab. 10). Besides the 2.3 million new "civil" cases in 2008, Japanese filed 766,000 domestic relations suits in family courts.

4. England and Wales. -- In England and Wales, plaintiffs filed 2.01 million civil suits in county courts in 2007 . In addition, they filed 127,664 family law cases. ${ }^{13}$ As in the U.S. and Japan, most suits involved "money claims." Of 2 million filings in 2007, 1.6 million were money claims, 284,000 were for recovery of land, 8,000 for return of goods, and 67,000 for insolvency. ${ }^{14}$

5. Canada. -- In the year ending 2009, plaintiffs filed 324,015 general civil cases (including small claims) in the seven Canadian provinces of Nova Scotia, Ontario, Alberta, B.C., Yukon, Northwest Territories, and Nunavut. They filed another 175,628 family law cases. An English colony, a common-law legal system, a North-American neighbor -- yet Canada has but a quarter of the litigation in the U.S. Indeed, it has less litigation per capita even than the famously "non-litigious" Japanese.

6. Australia. -- Like the U.S. and Canada, Australia maintains a federal structure for its courts. It couples one federal (i.e., national) court system, with separate court systems in each of its eight states. We were able to obtain data on court filings for six of the eight, an area with about 90 percent of the Australian population. Plaintiffs in these states filed 302,000 suits (allocating the federal filings by population). ${ }^{15}$

7. France. -- France has four kinds of specialized trial courts. In 2006 plaintiffs filed 943,597 new cases in the Tribunaux de grande instance (general law, large suits), 614,480 in the Tribunaux d'instance (general law, small suits), 3,294 in the Tribunaux paritaires des baux ruraux (rural areas), 198,455 in the Conseils de prud'hommes (employment disputes), and 193,534 in the Tribunaux de commerce (commerce). This yields a total of 1,953,360 suits, of which 422,790 were family law cases. Adding the remaining 1,530,570 non-family civil suits yields a litigation rate of 2,416 per 100,000 people.

8. Qualifications. -- We enter these calculations in the first row of Table 1. The numbers reflect with reasonable accuracy what they purport to measure: the number of times

\footnotetext{
${ }^{13}$ U.K. Ministry of Justice, Judicial and Court Statistics 2007, Tables 4.1 and 5.1.

14 U.K. Ministry of Justice, Judicial and Court Statistics 2007, table 4.1.

${ }^{15}$ Based on annual reports filed by the various courts, and available from their websites.
} 
people file non-family civil suits in court. They only haphazardly proxy for the role courts play in society. Although the number of filings might seem to measure that role, consider the following three complications.

a. Small-claims courts. If one were interested in the extent to which people use the courts to resolve economically substantial disputes, however, one might want to exclude the very smallest claims. And if one wanted to measure the role courts played in society, a small suit obviously should count for less than a large one. Since states and countries differ in their cutoffs, however, omitting small-claims courts could be highly misleading; one country's figure might still include mostly petty disputes while another's did not.

b. The definition of "case"' The same category of disputes does not generate the same number of cases in every country. Take divorce, which in the U.S., will almost always lead to a measured case: to divorce, a couple generally must file a suit in court. By contrast, in Japan most divorces never enter court records. To part ways, a couple simply goes to city hall and enters a divorce on the "family registry." Only when they can't agree on the divorce terms will they appear in family court. Only 12 percent of divorces end up in court, and only 1 percent actually go to trial. ${ }^{16}$ Naturally, American couples would thus appear to be more litigious.

Or suppose John Doe reneges on his credit card debt. In any country, if the lender wants to force him to pay it will need to file suit. It may try a variety of extralegal harassing tactics first, but to get at Doe's bank account or paycheck, court permission is needed. If instead, Doe borrows at a pawn shop and does not pay, the lender merely keeps (and eventually sells) the pawned object. The dispute becomes a case only if the borrower wants to force the lender to return the object pawned. As a result, the number of cases filed in court will depend on the relative prevalence of creditcard and pawn-shop finance in the consumer credit market --- which will vary from country to country. ${ }^{17}$

Pawnshops do not make headlines, but they do matter to aggregate statistics. In the U.S., for example: a 1988 study found 6,853 pawnshops making an estimated 35 million loans per year. In Tokyo, only 700 pawn shops remain today -- most consumer instead borrow through credit cards, real estate mortgages, and unsecured loans. In 1955, however, over 21,000 pawn shops operated in Japan. Japanese file more suits today than they did in 1955. Part of that increase, however, reflects neither legal nor cultural change. It merely reflects the shift in consumer finance technology from pawn shop loans to unsecured lending through the formal financial sector. ${ }^{18}$

\footnotetext{
${ }^{16}$ Kosei rodo sho, Rikon ni kansuru tokei [Divorce Statistics] 21 (Tokyo: Kosei tokei kyokai, 2009).

17 John P. Caskey, "Pawnbroking in America: The Economics of a Forgotten Credit Market," Journal of Money, Credit, and Banking, 23 (1991) 85-100.

${ }^{18}$ Kosei rodo sho, Kosei hakusho [Public Health White Paper] (Tokyo: Kosei rodo sho, 1956), http://www.lufimia.net/sub/pawn/history.htm;http://sss888.net/acom/tire/under.html;

http://www.acom.co.jp/company/outline/history
} 
c. Predictability. How often plaintiffs sue also turns on courts' predictability. ${ }^{19}$ Litigation is more expensive than settlement. If the disputants know that the court will award amount $\mathrm{X}$, they can just transfer the $\mathrm{X}$ by themselves and pocket the fees they would otherwise have paid their lawyers. If you know what a judge will do anyway, why pay to have a trial in two years and ask him?

Disputants litigate rather than settle only if they each hold optimistic estimates of their prospects in court. Because they face higher expenses if they litigate than if they settle, that cost difference creates a "settlement window." So long as the difference in their estimates of the litigated outcome is smaller than that settlement window, they both gain by settling. Only if they disagree enough about what the judge will do will they pay their lawyers and take their chances.

If we want to measure court activity, then we do want the number of filings and trials rather than the amount of claims asserted in the shadow of the law. A country with more erratic courts (e.g., the United States with its civil juries) will have more litigation than a country with predictable courts (e.g., Japan with its bureaucratic judges). On the other hand, if we want to measure the amount of wealth transferred according to legal rules, then we would instead like to include settlements. For example, we might define "litigious" citizens to include disputants who extract damages by asserting their legally protected rights even if they rationally and self-interestedly settle their claims. Under that definition, a country might be "litigious" even with few suits or judges per capita.

Traffic accidents in Japan. The course of traffic accident disputes in Japan illustrates this dynamic. As Japan emerged from the devastation of World War II, very few people owned cars. By the 1960s, the economy was growing at double-digit rates each year. Increasingly, Japanese chose to spend what they earned on automobiles. As they did, they increasingly killed each other on the roads. Accidents boomed, and so did litigation (even without a change in the court system, to recall our earlier point).

After traffic accident cases began to increase rapidly, the Tokyo District Court established a special traffic section in 1962. As Dan Foote (1995) recounts, the new panel immediately found itself swamped. Quickly, the traffic section realized it had to routinize its treatment of cases. At first, it kept its formulas internal to the courts. It published handbooks for judges detailing its "rules of thumb for damages" and standards on comparative negligence. In time, however, the Tokyo traffic section took its dissemination efforts beyond the courts. It began announcing its rules to the bar and the public. The culmination came with what Foote describes as "a special 161-page issue of [one of the principal legal journals] in 1975 consisting entirely of explanations of the compensation and comparative fault standard used by the courts." 20

From 1964 to 1968, the number of suits filed in district courts over traffic accidents more than doubled, from 2,378 to $5,514,{ }^{21}$ rising from 3 to 7 percent of civil

19 The classic explanations are: William M. Landes, “An Economic Analysis of the Courts," Journal of Law and Economics, 14 (1971) 61-xxx; Richard A. Posner, "An Economic Approach to Legal Procedure and Judicial Administration,’’ Journal of Legal Studies, 2 (1973) 399-xx.

${ }^{20}$ Daniel H. Foote, Resolution of Traffic Accident Disputes and Judicial Activism in Japan, 25 L. Japan 19, 27, 29 (1995).

21 _J. Mark Ramseyer \& Minoru Nakazato, "The Rational Litigant: Settlement Amounts and Verdict Rates in Japan," J. Legal Stud., 18 (1989) 263; Saiko saibansho, ed. Shiho tokei nempo [Judicial 
suits. After 1971, the number of suits began to fall. Plaintiffs filed 11,118 traffic claims that year (14 percent of all suits). By 1975, they filed only 5,808 (8 percent of all suits), and by 1980 only 3,484 (3 percent of all suits). Indeed, writes Foote, by the end of the decade the judges in the Tokyo traffic section found themselves "at loose ends due to lack of work. Beginning in 1978, [they] began handling workers' compensation cases, as well as automobile cases, since there was no longer enough traffic accident litigation to keep [them] busy."22

With better highways, automatic stoplights, additional sidewalks, and safer cars, the number of deaths from traffic accidents plummeted from 21,535 in 1970 to 11,752 in 1980. Yet the number of cases filed fell faster still, from 11,620 to 3,484 -- a 70 percent drop. Civil litigation in general did not fall. In 1970, plaintiffs filed 74,733 non-traffic suits; by 1980, they filed 102,075.

Although they increasingly took their disputes out of the courts during the 1970s, Japanese traffic-accident disputants still settled by the expected court outcome. Ramseyer and Nakazato compared the amounts paid by automobile insurers in wrongful death claims with the amounts awarded the heirs to accident victims in court. ${ }^{23}$ In virtually all cases where heirs would have had legal claims against drivers, they obtained compensation from the drivers' insurers. Out of court, they collected mean amounts that closely tracked the mean amounts courts would have awarded.

Thus, cases filed per capita do not provide a good measure even of first-order law, if by that we mean the extent to which the courts are influential in resolving first-order disputes. They provide a somewhat better measure of how much the courts decide directly rather than indirectly, but even then they do not provide a good measure of the importance of the wealth transfers.

\section{Judges per Capita:}

1. The numbers. -- As an alternative index for the role courts play in society, take the number of judges. This would address to some extent the problem of suits varying in importance, since more important suits require more time from judges.

In the U.S., the state courts employed 29,379 judges in 2004 (CSP, 2004). The federal government employs 875 constitutionally authorized judges (2009; "Article III" judges with life tenure), ${ }^{24}$ and another 352 to work as Bankruptcy Judges, 567 as Magistrate Judges, ${ }^{25}$ and 1,422 as Administrative Law Judges. ${ }^{26}$ Added up, we have 32,595 , or 10.81 per 100,000 .

Statistics Annual] (Tokyo: Saiko saibansho, various years); traffic deaths from Japanese Ministry of Health \& Welfare.

${ }^{22}$ Foote, supra note, at 30.

${ }^{23}$ J. Mark Ramseyer and Minoru Nakazato, "The Rational Litigant: Settlement Amounts and Verdict Rates in Japan,’’ The Journal of Legal Studies, 18 (1989) 263-90.

24 Office of the U.S. Courts, "Federal Judgeships," http://www.uscourts.gov/JudgesAndJudgeships/FederalJudgeships.aspx.

${ }^{25}$ p. 36, Administrative Office of the United States Courts. 2009 Annual Report of the Director: Judicial Business of the United States Courts. Washington, D.C.: U.S. Government Printing Office, 2010. 
In 2010, the Japanese courts employed 15 Supreme Court Justices, 8 High Court Presidents (chief judges), 1,782 Judges (trial and intermediate appellate), 1,000 Assistant Judges (judges in their first ten years of employment), and 806 Summary Court Judges (not all of them legally trained), a total of 3,61, ${ }^{27} 2.83$ per 100,000 population.

In 2008, England and Wales employed 110 High Court judges, 653 Circuit Judges, and 438 District Judges, a total of $1,201{ }^{28}$ or 2.22 per 100,000 . The High Court judges hear criminal appeals and difficult civil cases. Circuit Judges and District Judges staff the County Courts and hear family and most civil cases. The Crown Courts do not hear civil cases, but they do use Circuit Judges. In addition, there were 1,305 Recorders and 29,419 Justices of the Peace. Recorders are part-time judges, who sit for 2 percent of the judge-days in High Courts, 22 percent in County Courts, and 3 percent in xxxCounty CEHCK ON THIS Courts. Justices of the Peace are lay magistrates who handle minor criminal cases. Although not full judges, they do handle cases that judges would handle in the United States.

Given its federal structure, Canada employs judges in both its federal (national) and provincial courts. It had about 80 federal judges, and 1,100 state judges, or 3.3 per 100,000 population. $^{29}$

Australia similarly employs judges and magistrates in both federal and state courts. It has about 100 federal judges, and about 740 state judges, or 4.00 judges per 100,000 population. $^{30}$

The French courts employ 7,896 Magistrats de l'ordre judiciaire. ${ }^{31}$ Per 100,000 population, that's 12.47 .

2. Qualifications. Our discussion of the English courts shows that measuring the number of judges is not as simple as it seems, since "judge" is an ambiguous term when several different levels of adjudicators exists. Moreover, we lightly passed over the problem that judges deal with criminal as well as civil cases, and the ratio between the two cases differs between countries. As with the number of suits filed, however, the problem with the number of judges lies less in the numbers themselves than in their significance. From

http://www.uscourts.gov/FederalCourts/UnderstandingtheFederalCourts/AdministrativeOffice/DirectorAnn ualReport.aspx

${ }^{26}$ p. 2, Vanessa K. Burrows “Administrative Law Judges: An Overview,” Congressional Research Service, April 13, 2010, http://towmasters.files.wordpress.com/.../administrative-law-judges-anoverview.pdf

${ }^{27}$ Saiban sho shokuin teiin ho [Act Authorizing the Number of Employees in

the Courts], Law No. 53 of 1951, as amended March 31, 2010. http://law.egov.go.jp/htmldata/S26/S26HO053.html

${ }^{28}$ Ministry of Justice, Judicial and Court Statistics 2007, Table 9.1. (Useful supplements to the cited documents are: Wikipedia: http://en.wikipedia.org/wiki/Courts_of_England_and_Wales, http://en.wikipedia.org/wiki/Judiciary_of_England_and_Wales)

${ }^{29}$ http://www.fja.gc.ca/appointments-nominations/judges-juges-eng.html.

${ }^{30}$ Compiled from annual reports for the various courts, available on the official web sites.

31 INSEE, Moyens en personnel la Justice, http://www.insee.fr/fr/themes/tableau.asp?ref_id=NATnon05317\&reg_id=0. 
time to time, observers use the number of judges to proxy for the demand for judicial services. Implicitly, they suggest that governments appoint the judges they do because people file the lawsuits they do. In fact, however, causation just as plausibly runs the other way. People may file the suits that they do because of the number of judges the government has appointed. With more judges, trial dates will come sooner, and plaintiffs will sue more and have less time to settle. ${ }^{32}$

\section{Lawyers per Capita:}

1. The numbers. -- We measure the number of lawyers per 100,000 population to be 380 in the United States, 12 in Japan, 277 in England, 292 in Canada, 259 in Australia, and 70 in France. ${ }^{33}$

2. Qualifications. -- As often discussed, ${ }^{34}$ the number of lawyers captures the social importance of law only imperfectly at best. In many societies, lawyers sell services only tangentially related to the law and unrelated entirely to courts. In other societies, a wide variety of non-lawyers sell law- and court-related services. Some lawyers do litigate, of course. In Japan, until recently they seldom did anything else. Because the government recognized their monopoly only on litigation-related services, they focused on litigation. In the U.S., only a minority of lawyers actually litigate. And in the U.K., all barristers traditionally litigated, while no solicitors did. In some countries, lawyers counsel. Although in Japan traditionally lawyers rarely gave business or personal advice, in the U.S. most lawyers do routinely. In the U.K. solicitors give business advice, while barristers did not. Some lawyers do nothing legal at all. Many American lawyers abandon their legal practice within a few years. Elsewhere, lawyers stay with their profession their entire life.

Some countries may have few licensed lawyers, while a wide variety of nonlawyers sell legal services. Again, take Japan. Among the countries in Table 1, it has the fewest lawyers: less than a tenth as many as the U.S., England, Canada, or Australia, and less than half as many as France. The reason is simple: for most of the post-war

${ }^{32}$ This is explained in George L. Priest, "Private Litigants and the Court Congestion Problem," Boston University Law Review, 69 (1989) 527.

33 American Bar Association, National Lawyer Population by State, http://new.abanet.org/marketresearch/PublicDocuments/2009_NATL_LAWYER_by_State.pdf.

"Membership JFBA,” http://www.nichibenren.or.jp/ja/jfba_info/membership/index.html. "Number of lawyers in CCBE Member Bars” http://www.ccbe.eu/fileadmin/user_upload/NTCdocument/table_number_lawyers1_1179905628.pdf.

Federation of Law Societies of Canada. http://www.flsc.ca/en/about/about.asp. Considerable variation exists by state in Australia, in the regulation of the bar. Questioned by the Japan Federation of Bar Associations, the Law Council of Australia estimated the number of lawyers in Australia in 2006 at 58,000. http://www.nichibenren.or.jp/en/directory/data/Australia.pdf. However, Australian Bureau of Statistics found that in 2008 the legal services industry "employed" (apparently including non-lawyers) 99,696 persons. Australian Bureau of Statistics, 8667.0 - Legal Services, Australia, $2007-08$. http://www.abs.gov.au/AUSSTATS/abs@.nsf/Latestproducts/8667.0Main\%20Features32007-

08? opendocument\&tabname=Summary\&prodno=8667.0\&issue=2007-08\&num=\&view= .

${ }^{34}$ Including by us; see Minoru Nakazato, J. Mark Ramseyer and Eric B. Rasmusen, “The Industrial Organization of the Japanese Bar: Levels and Determinants of Attorney Income,’ Journal of Empirical Legal Studies, 7 (2010) 460--xxx. 
period, the government set the pass rate on the bar exam below 3 percent. Even when they could not afford (or even find) a lawyer, however, Japanese citizens could buy legal services. They could turn to licensed tax agents for tax advice. They could consult licensed patent agents on intellectual property. They could obtain wills and corporate charters from notary publics. And firms could obtain their corporate and contract advice by hiring unlicensed graduates of the many college law departments.

Given these objections, some scholars look not at licensed legal practitioners, but at university graduates with legal training. By this metric, Japan has more legal experts even than the U.S. Using this approach, Kevin Murphy, Andrei Shleifer, and Robert Vishny index the amount of rent-seeking in a society by the size of university law departments. ${ }^{35}$ Averaging across a large number of countries, both developed and developing, they find that the more law graduates in a society, the slower its GDP will grow. Conversely, the more engineering students it graduates, the faster that GDP will grow. The example of Japan versus the United States shows that this approach is fraught with peril: not all those with undergraduate law degrees work in the law business, just as not all those with history degrees work in the history business.

\section{E. Ease of Doing Business:}

In its well-known "Doing Business" studies, the World Bank measures the difficulty of performing various small business tasks in different countries. The specificity of the tasks measured is an attractive feature of the approach. Table 6 shows the results the Bank obtained for the difficulty of enforcing a contract. ${ }^{36}$ According to the Bank, firms in our six wealthy democracies require similar numbers of procedures to enforce a deal. They will spend 300-400 days in all of the countries except Canada, and consume 14-24 percent of the money at stake.

We include sub-Saharan Africa in Table 6 to show how first-order measures differ between developed and developing countries. The region includes primarily dysfunctional economies and the legal framework in the area reflects (and contributes to) the dysfunction. A sub-Saharan firm that tried to enforce a contract in court would file nearly 40 procedures, spend over 600 days, and consume nearly half of its claim.

\section{Table 6: The Difficulty of Enforcing Contracts}

\begin{tabular}{|c|c|c|c|}
\hline Country & Procedures (number) & Time (days) & Cost (\% of claim) \\
\hline Australia & 28 & 395 & 20.7 \\
\hline Canada & 36 & 570 & 22.3 \\
\hline France & 29 & 331 & 17.4 \\
\hline Japan & 30 & 360 & 22.7 \\
\hline United Kingdom & 30 & 399 & 23.4 \\
\hline
\end{tabular}

${ }^{35}$ Kevin M. Murphy, Andrei Shleifer and Robert W. Vishny, "The Allocation of Talent: Implications for Growth,’ Quarterly Journal of Economics, 106 (1991) 503--xxx. 36
http://www.doingbusiness.org/ExploreTopics/EnforcingContracts/. 


\begin{tabular}{lccc} 
Sub-Saharan Africa & 39 & 644 & 49.3 \\
United States & 32 & 300 & 14.4 \\
\hline & $\ldots$
\end{tabular}

Contract disputes are an important area of first-order disputes. A very different way to measure the efficiency of the courts, at least for developed countries, is through insurance data. Take two countries, A and B. In country A, the courts handle first-order disputes efficiently. The courts sent clear signals about liability and damages. Victims, drivers, and insurers can readily ascertain whether a driver owes money and, if he does, how much. In country B, the courts send only confused signals. If the parties try to learn the driver's liability in court, they find that litigation entails high costs and the result is unpredictable. Suppose that drivers in the two countries cause the same number of accidents, and that the courts value human life at the same level. Given the higher administrative costs involved, insurance will cost more in B than in A. If country B's courts also consistently overestimate the extent of liability and damages, insurance costs will be still higher.

In Table 7, we give the OECD's estimates of the mean automobile insurance costs in various countries. Among the 22 countries, only in Canada and Ireland do drivers face higher costs than in the U.S. Where American drivers pay \$1,464 per car, British drivers pay $\$ 924$. French drivers pay only \$786, Japanese pay \$754, and Australians \$664. The data suggest American courts handle first-order disputes quite badly.

Table 7: Motor Insurance Costs

\begin{tabular}{|c|c|c|c|}
\hline \multirow[t]{2}{*}{ Country } & \multicolumn{3}{|c|}{ Motor } \\
\hline & $\begin{array}{ll}\text { (per } & 1,000 \\
\text { people) } & \end{array}$ & (US \$ per car) & (\% of GDP) \\
\hline Australia & 545 & 664 & 0.81 \\
\hline Austria & 511 & 332 & 0.38 \\
\hline Belgium & 471 & 834 & 0.91 \\
\hline Canada & 372 & 1,574 & 1.35 \\
\hline Czech Republic & 414 & 456 & 1.12 \\
\hline Denmark & 370 & 1,334 & 0.87 \\
\hline Finland & 483 & 634 & 0.66 \\
\hline France & 498 & 786 & 0.93 \\
\hline Germany & 566 & 792 & 1.11 \\
\hline Greece & 429 & 467 & 0.72 \\
\hline Hungary & 300 & 425 & 0.92 \\
\hline Ireland & 437 & 1,582 & 1.15 \\
\hline Italy & 601 & 830 & 1.40 \\
\hline Japan & 325 & 754 & 0.72 \\
\hline Korea, Rep. & 248 & 949 & 1.09 \\
\hline Netherlands & 441 & 903 & 0.84 \\
\hline
\end{tabular}




$\begin{array}{llll}\text { Norway } & 458 & 1,103 & 0.61 \\ \text { Spain } & 485 & 785 & 1.19 \\ \text { Sweden } & 465 & 1,001 & 0.94 \\ \text { Switzerland } & 524 & 1,131 & 1.05 \\ \text { United } & & & \\ \text { Kingdom } & 463 & 927 & 0.93 \\ \text { United States } & \mathbf{4 5 1} & \mathbf{1 , 4 6 4} & \mathbf{1 . 4 5}\end{array}$

Source: OECD, Insurance Statistics Yearbook 1998-2007, 2007 data. Exchange rates, population, and GDP used in the calculations are from the World Bank, WorldDataBank, http://databank.worldbank.org/ddp/home.do.

The numbers in Table 7 are misleading, however. Insurance rates are secondhighest in the U.S. because Americans drive more and crash more. Look at Table 8. The number of traffic deaths per car in the U.S. is second highest. The number of traffic accidents per car in the U.S. is second highest. And the distance travelled per car in the U.S. is the very highest. Given how far Americans drive their cars, how many accidents they have, and how many people they kill, insurance premia do not seem out of line.

Table 8: Traffic Safety

$\begin{array}{lllll}\text { Country } & \begin{array}{l}\text { Insurance } \\ \text { Per Car }\end{array} & \begin{array}{l}\text { Traffic } \\ \text { Deaths/Car }\end{array} & \begin{array}{l}\text { 1000*Accid } \\ \text { Per Car }\end{array} & \text { Km/Car } \\ \text { Australia } & 664 & 140 & & 18,088 \\ \text { Belgium } & 834 & 213 & & \\ \text { Canada } & \mathbf{1 , 5 7 4} & 235 & 11.80 & \mathbf{2 6 , 7 1 9} \\ \text { Czech } & & & & \\ \text { Republic } & \mathbf{4 5 6} & 286 & & \\ \text { Denmark } & 1,334 & 201 & 2.64 & 17,031 \\ \text { France } & 786 & 150 & 7.21 & 14,340 \\ \text { Germany } & 792 & 106 & 6.67 & \\ \text { Italy } & 830 & 144 & \mathbf{2 0 . 0 1} & 18,341 \\ \text { Japan } & 754 & 160 & & \\ \text { Korea } & 949 & \mathbf{5 1 1} & 3.57 & 17,283 \\ \text { Netherlands } & 903 & 98 & & \\ \text { Norway } & 1,103 & 108 & & \\ \text { Spain } & 785 & 175 & & \\ \text { Sweden } & 1,001 & 110 & & \\ \text { Switzerland } & 1,131 & \mathbf{9 7} & & \end{array}$


United

$\begin{array}{lllll}\text { Kingdom } & 927 & 108 & 6.66 & 16,323\end{array}$

United

$\begin{array}{lllll}\text { States } & 1,464 & 302 & 13.14 & 35,315\end{array}$

Sources: OECD, International Traffic Safety Data and Analysis Group (IRTAD), http://www.internationaltransportforum.org/irtad/.

As a final measure of litigation, we mention the analysis of tort costs by the consulting firm Towers-Perrin-Tillinghast (now part of Towers-Watson), well known for its measurements of tort costs over time in the United States. Its annual U.S. estimates, still coming out each year, use the extensive data on insurance premiums collected by A.M. Best for sale primarily to businesses, with adjustments for such things as selfinsurance. Those reports describe methodology clearly and break down the data into categories that allow its construction to be understood. Its international studies, however, which ended in 2006, do not describe their methodology or data sources. ${ }^{37}$ Aside from the OECD data that we used for the discussion of motor insurance earlier, we are not aware of international data sources that would be available, so we are skeptical of the numbers in Table 9. Nonetheless, because they are so well-known we reproduce them below.

Table 9: The TTP Estimates of Litigation Costs

$\begin{array}{lllll}\text { Country } & 2000 & 2001 & 2002 & 2003 \\ & & & & \\ \text { Belgium } & 1.00 \% & 1.08 \% & 1.01 \% & 0.96 \% \\ \text { Denmark } & \text { N/A } & 0.44 & 0.48 & 0.58 \\ \text { France } & 0.75 & 0.75 & 0.76 & 0.74 \\ \text { Germany } & 1.25 & 1.25 & 1.19 & 1.14 \\ \text { Italy } & 1.75 & 1.72 & 1.70 & 1.70 \\ \text { Japan } & 0.79 & 0.80 & 0.81 & 0.80 \\ & & & & \\ \text { Poland } & \mathrm{N} / \mathrm{A} & \mathrm{N} / \mathrm{A} & 0.60 & 0.59 \\ \text { Spain } & 1.04 & 1.03 & 1.01 & 1.04 \\ \text { Switzerland } & 0.63 & 0.69 & 0.81 & 0.75 \\ \text { UK } & 0.53 & 0.64 & 0.66 & 0.69 \\ \text { U.S.A. } & 1.82 & 2.03 & 2.22 & 2.23\end{array}$

${ }^{37}$ The report says on p. 12, “To estimate tort costs in 10 other countries, we used a methodology similar to the one we used to estimate U.S. tort costs. ... The data available in the analyses of non-U.S. tort costs, particularly the self-insurance component, are limited.” 
Source: U.S. Tort Costs and Cross Border Perspectives: 2005 Update, p. 12. Towers Perrin Tillinghast, 2006.

\section{American Dysfunction}

A. Introduction:

Most of the measures we examined above suggest that America is not that unusual. In suits per capita, the ratio between the US and the UK is less than between the UK and Canada. Americans do have more judges per capita, but fewer than the French, and "judge" is hard to define anyway. Americans have the most lawyers per capita, but not many more than Australians. And Americans seem not to find contracts especially hard to enforce or to face unusually high automobile insurance premia.

Why, then, the American notoriety? It does not result from the way the legal system handles routine disputes. Instead, it derives from more special areas of law. We will look at two as examples: securities class actions and asbestos torts. Although aggregate quantitative measures suggest that litigation in the U.S. does not differ substantially from litigation elsewhere, aggregation over myriad categories can easily hide a myriad of sins. In several discrete areas, American courts function in a manner one can only describe as disastrous.

\section{B. Securities Class Actions:}

1. The mechanism. -- Within the U.S. legal system, class actions are a particular scourge. A small fraction of suits, they wreak havoc out of proportion to their numbers. As a form of group litigation, they have antecedents in colonial times. As "class actions," they date to Rule 23 of the 1938 Federal Rules of Civil Procedure. But in their modern, rampantly abused form they date to the 1967 revisions of Rule 23.

The drafters of the modern class action tried to designed a mechanism that would let victims cost-effectively prosecute claims for wrongs that impose large losses on the community as a whole but trivial damages on any one victim. Suppose a firm negligently pollutes and causes damages of \$1 million to nearby land. If one person owns that land, he will sue for the $\$ 1$ million. For damages that large, it is worth hiring a lawyer. With a credible threat to sue, he can demand $\$ 1$ million in settlement out of court.

Suppose the firm had not one but 1,000 neighbors, each owning a small piece of the damaged land. The firm has caused the same aggregate injury, but no one of the victims could hire a lawyer for less than the amount he could win in court. Since none of the 1,000 would sue, none could credibly threaten to sue. Unable to threaten credibly, none would recover anything out of court.

Suboptimal precautions will result. If the firm faced one neighbor, it would pay for any negligence, and therefore would adopt efficient precautions against pollution. Facing 1,000 neighbors, it escapes liability for its negligence and so neglects precautions. The class-action suit eliminates that misincentive by imposing the same incentives the firm would face if just one person owned the land.

So far, so good. But there is a hitch. Someone has to initiate the suit. Under the U.S. system, a lawyer with an eye for an opportunity masterminds the class-action suit. He identifies a legal wrong and locates several victims. He suggests that they retain him 
to sue on behalf of them and all others "similarly situated." They and the others have the right to "opt out" of the litigation and pursue their claims independently. Should they not opt out, they will find themselves bound by whatever outcome the lawyer obtains: the suit has "claim preclusive" effect. The clients are too scattered to control the lawsuit, so the lawyer does that. As an incentive, he collects a contingency fee.

The class action mechanism is a creature almost exclusively of the American legal system. Although some European countries have considered adopting the class action, the main venues that have done so are a few Canadian provinces, Australia, and Brazil. ${ }^{38}$ Why not adopt, if the incentive effect is so desirable?

2. Problems. -- Agency problems plague the attorney-client relationship in the best of situations, but class actions reach the ultimate in agency slack. Because each plaintiff has only a small stake in the litigation, no one of them even tries to monitor the lawyer. He operates as an autonomous actor: independent, unmonitored, and free to pursue his own interests. As the pre-eminent class-action lawyer William Lerach once infamously bragged (now, for his litigation tactics, a convicted felon): "I have the best practice in the world. I have no clients."

The class-action attorney's misaligned incentives particularly skew settlements. Given the trivial size of their claim, few victims pay attention to settlement bargaining. The defendant can take advantage of that by negotiating a settlement that is generous to the lawyers and stingy to his clients. The attorney agrees to take a generous fee, always in cash, and a much smaller recovery for his clients, often "in-kind" as free samples of the defendant's product.

The class-action rules do require the judge to approve any settlement, precisely to avoid this problem. Because the attorneys for both sides favor the settlement, however, nobody will criticize it in court. Accustomed to an adversarial system in which they seldom take initiative, judges defer. They are busy people. They like to please at least some of the people in front of them. And they are linked by social interactions, gratitude for appointment (if by "merit panel"), the old school tie, or campaign contributions to attorneys, defense and plaintiff, not to citizens without J.D.'s. Too often, the important conflict is not between the plaintiff and the defense with the judge staying neutral, but between the lawyers and the non-professionals.

3. Securities class actions. -- Even within class actions, securities claims are notorious. Attorneys locate firms whose share price has fallen. They then argue that the firms (or the firms' officers, whom the firms will typically indemnify) caused the fall through misconduct--- mismanagement, conflicts of interest, or misrepresentations. To recover the loss in the firm's market capitalization, the attorneys sue on behalf of the shareholders.

Until the mid-1990s, judges named a firm to the lucrative "lead attorney" role if it filed the first claim. Filing first, asking questions later, attorneys raced to the courthouse when share prices fell, and looked for misconduct later. The 1995 Private Securities Litigation Reform Act was supposed to change that. The Act told judges to

${ }^{38}$ Thomas D. Rowe, Jr., "Foreword: Debates over Group Litigation in Comparative Perspective: What Can We Learn from Each Other," Duke Journal of Comparative and International Law, 11 (2001) $157,157-59$. 
pick as lead plaintiffs those with the largest financial claims rather than those who file first. According to Stephen Choi and Adam Pritchard (2009: 113-15), however, the problem remained. The trial lawyers simply switched their effort from racing to the courthouse to courting institutional investors. Commercial mutual funds generally rejected being plaintiffs, so attorneys mostly recruited the more politicized governmentsponsored funds and labor union pension plans.

Any financial gain to investors from even a successful suit is minimal. Suppose a firm settles for $\$ 30$ million--- a third to the attorneys and two thirds to the plaintiffs. Because the firm pays the settlement, its market value falls even more. In effect, the firm's current shareholders pay the damages. Because the settlement goes to the shareholders at the time of the alleged misconduct (many of whom still own their shares in the firm), those former shareholders receive cash. The settlement reduces the value of the stock held by one group of investors, increases the cash held by an overlapping group of investors (but by one third less, subtracting the lawyers fees), and enriches the law firm that engineers the transfer.

4. Magnitudes. -- From 1996 to 2009, , the number of securities class action suits exceeded 300 only once (514 in 2001), and in 2006 it was only 131 . Recall that in a typical year plaintiffs in the United States file 272,000 federal suits and 18 million state suits. Securities class actions are a wart on a whale.

Yet to settle these few suits firms pay dearly. In 2009, there were 221 new filings. The mean settlement value that year was 13 million dollars, the total was 2.8 billion, and the total attorney fees plus expenses were .963 billion. ${ }^{39}$ The problem is not that firms lose in court. Of 238 suits filed in 2000, by mid-2010 the parties had settled 146 and judges had thrown out 85. Of the remaining 7, only 4 had gone to trial -- and the parties settled all 4 before the verdict. More generally, since the 1995 PSLRA, plaintiffs have filed over 3,400 securities class actions in federal courts, and only 27 went to trial, about 1 in 1,000. Of those, plaintiffs won 6 and obtained a mixed verdict in 5. Thus, of the 3,400 suits since 1995 , plaintiffs won anything at all in court in only $11 .{ }^{40}$

Nonetheless, firms have paid out massive amounts. In 60 percent of cases, the defendants settle, most for 20 to 60 million dollars, but some for more. The largest 10 settlements up to July 2010 transferred over 1 billion dollars each, the largest being Enron's 7.2 billion dollars in 2010 and WorldCom's 6.2 billion dollars in 2005. ${ }^{41}$

The few other countries with class action provisions manage to avoid these large transfers. Australia introduced class actions in 1992. In no year since have attorneys filed more than 6 securities class actions. ${ }^{42}$ Some Canadian provinces have offered class

${ }^{39}$ Jordan Milev, Robert Patton, Stephanie Pnacich \& Svetlana Starykh, Trends 2010 Mid-Year Study: Filings Decline as the Wave of Credit Crisis Cases Subsides, Median Settlement at Record High (NERA Economic Consulting, 2010), Figures 1, 18, 19, 20.

${ }^{40}$ Milev, et al., supra note, at 16, 19, Fig. 13.

${ }^{41}$ Milev et al., Table 2.

${ }^{42}$ Greg Houston, Svetlana Starykh, Astrid Dahl \& Shane Anderson. 2010. Trends in Australian Securities Class Actions: 1 January 1993-31 December 2009. NERA Economic Consulting. 
actions since 1978. Attorneys did not file the first securities class action until 1997, however, and in no year have attorneys filed more than $9 .{ }^{43}$

American securities class actions are not simple transfers from one group of investors to another. The plaintiffs' bar imposes a massive toll charge on the transfer. For engineering the transfers from one set of investors to another, they charge over $\$ 400$ million a year. In each of the years 2005, 2006, and 2007 they took over $\$ 1$ billion.

5. Politics. -- Why do Congress and the courts let securities class actions continue? The answer lies in the politics of the bar. Attorneys in all sectors give heavily to the Democratic Party. In 2008, attorneys with Chicago’s Sidley \& Austin gave \$1.4 million to politicians, 81 percent to Democrats. Sidley was, to be sure, the scene of the 1980's romance between Barak and Michelle Obama, but other large firms gave heavily to Democrats too. Sidley's Chicago rival, Kirkland \& Ellis, gave \$1.3 million, 76 percent to Democrats. New York’s Skadden Arps gave \$1.7 million, 82 percent to Democrats, and even the more traditional Sullivan \& Cromwell -- the quintessential "Wall Street establishment" firm -- gave $\$ 1.2$ million, 75 percent to Democrats. ${ }^{44}$ The trade association for the plaintiff's bar gives even more, and more overwhelmingly to Democrats. That group in 2008 gave over \$3 million to politicians, 95 percent to Democrats. $^{45}$ It lobbies hard against tort reform of all kinds and particularly hard against reform of the securities class action. By all odds, it was because of ATLA pressure that Bill Clinton vetoed the 1995 PSLRA, only to find himself over-ridden by the heavily Republican Senate. $^{46}$

For a sense of the color involved, consider a phone call one of us received in the mid-1990s. At the time, Ramseyer taught at the University of Chicago Law School. The call came from an associate at a well-known law firm specializing in securities class actions. The associate explained that they wanted to retain Ramseyer in connection with a suit against a certain large Japanese corporation. The law firm had filed suit in an American state court, alleging misstatements in the firm's Japanese securities filings. "What did the firm misstate," Ramseyer asked. "We don't know," the associate answered. "That's why we want to retain you." It was enough that the stock price had fallen; the excuse to sue could always be found if they hired the right expert.

C. Asbestos:

1. Introduction. -- Mississippi plaintiffs' attorney Richard F. "Dickie" Scruggs called them "magic" jurisdictions:

The trial lawyers have established relationships with the judges that are elected; they're State Court judges; they're populists. They've got large populations of voters who are in on the deal, they're getting their piece in many cases. And so, it's a political force in their jurisdiction, and it's almost impossible to get a fair trial if you're a defendant in some of these places. ... The cases are

${ }^{43}$ Mark L. Berenblut, Bradley A. Heys \& Svetlana Starykh. 2009. Trends in Canadian Securities Class Actions: 1997-2008. NERA Consulting.

\footnotetext{
${ }^{44}$ http://www.opensecrets.org/industries/contrib.php?ind=k01\&cycle=2008

45 http://www.opensecrets.org/industries/contrib.php?ind=k01\&cycle=2008

${ }^{46}$ Stephen J. Choi and A.C. Pritchard. Securities Litigation 9Austin, Wolters Kluwer, 2008).
} 
not won in the courtroom. They're won on the back roads long before the case goes to trial. Any lawyer fresh out of law school can walk in there and win the case, so it doesn't matter what the evidence or law is. ${ }^{47}$

Scruggs made his first millions suing the asbestos companies in "magic" courtrooms. He made his first hundreds of millions suing the tobacco companies in the same places. He made millions more suing State Farm over its Katrina payments. After the harm was done, he went to prison in 2008 for bribing two of the "magic" judges in the asbestos and Katrina litigation,.

Few fields of tort litigation cut a broader swath through the American economy than asbestos. The Towers Perrin consulting firm estimates the total cost (compensation, attorney fees, and administrative expenses) of the U.S. tort system in 2003 at $\$ 246$ billion. Of that, $\$ 9$ billion was from asbestos. ${ }^{48}$ Asbestos was a miracle insulator. It did not conduct electricity. It did not burn. It absorbed sound. It was nonreactive with chemicals. Yet asbestos, if breathed could injure, and even kill, particular in combination with tobacco smoke. After a 20- to 40-year latency period, they could cause diseases ranging from asbestosis to mesothelioma to lung cancer. Asbestos is a necessary but not sufficient condition for mesothelioma and asbestosis, and a contributing factor for lung cancer. Estimates of the number of people asbestos killed range widely, from 40,000 to over 300,000 ffrom 1965 to $2009 .^{49}$

Tort law is an odd vehicle for asbestos harm remediation, and in some ways profoundly inappropriate. The people clearly hurt were those who encountered asbestos at work. Yet employers and employees negotiate contracts with each other in competitive markets. Employers choose to hire an employee if he offers the right combination of attributes (talent, effort, experience) at the lowest price (wages, insurance, and other benefits). Employees choose to work for a given firm if it offers the best mix of pay, environment, location, and other amenities. If an employer imposes a health risk, employees will agree to work there only if the firm promises a pay-and-amenity package that compensates for the risk.

Employers and employees do not always understand all the risks involved. As in any other contract, the optimal legal rule is the one that induces them to invest costjustified (but only cost-justified) resources in studying potential harms. The rule which does best is the rule that holds them to their promises, that bans intentional false statements, and that lets residual harms lie where they fall.

It has long been known that asbestos injures health. It is commonly written that Pliny the Elder suggested the use of respirators and noted that purchasers of slaves who had worked in asbestos mines should be mindful of their reduced lifespan. ${ }^{50}$ At least as

${ }^{47}$ Peter Boyer, “The Bribe,” The New Yorker, May 19, 2008, xxx.

48 Towers Perrin Tillinghast, U.S. Tort Costs: 2004 Update (2004), 2-3.

${ }^{49}$ Stephen J. Carroll, Deborah Hensler, Jennifer Gross, Elizabeth M. Sloss, Matthias Schonlau, Allan Abrahams and J. Scott Ashwood, Asbestos Litigation (Santa Monica: Rand, MG-162, 2005) at xix, 15-18.

${ }^{50}$ We repeat the Pliny story here, but it actually seems to be mythical, if omnipresent. Nobody gives a specific citation to Pliny's work. See K. Browne and R. Murray's letter, “Asbestos and the Romans," Lancet, 336 (1990) 445; also, Malcolm Ross and Robert P. Nolan, "History of Asbestos Discovery and Use and Asbestos-Related Disease in Context with the Occurrence of Asbestos within 
early as 1918, insurance companies were declining life insurance coverage to asbestos workers. $^{51}$ Henry Johns, founder of the largest asbestos company, Johns-Manville, died in 1898 of "dust phthisis pneumonitis. ${ }^{52}$ The very name of the ailment "asbestosis," coined in 1925, suggests that the danger was known. ${ }^{53}$ Workers may not have read Pliny, but surely they realized that breathing rock fibers was not healthful. The court concluded in the 1973 leading case that the plaintiff worker knew that his breathing of asbestos was bad for him, that workers frequently discussed the danger, and that the danger was wellknown in the medical literature:

2. History. - Asbestos litigation began with that 1973 case. The plaintiff had installed asbestos insulation for three decades. When he found himself with asbestosis and mesothelioma, he sued the manufacturers of the material his employers had told him to install. He knew the dust was bad for him, but not how bad, he argued, and the manufacturers had a duty to find out, track him down, and warn him of the dangers. The court agreed (Borel at 1086). The manufacturers were liable, under the doctrine of "strict liability" even though the plaintiff was guilty of "contributory negligence.” (Borel at 1106)

Asbestos litigation exploded. As of 2002, 730,000 plaintiffs had filed asbestosrelated claims. They sued 8,400 firms, 80 of which have now filed for bankruptcy (including Johns-Manville). Through the course of the litigation, the defendants paid (the Rand Corporation calculates) \$70 billion. They paid \$21 billion to their own lawyers, $\$ 19$ billion to the plaintiffs' lawyers, and $\$ 30$ billion to the plaintiffs themselves. ${ }^{54}$

70 billion dollars paid to deliver 30 billion dollars in compensation -compensation for which the plaintiffs negotiated off-setting pay packages ex ante anyway. What went wrong? Part of the cause lies in the legal doctrine itself. Asbestos users could have insisted that the sellers insure them against injury, but hey chose to bear the risk of loss themselves. Declaring tort to have supplanted the essential contractual character of the relationship, courts held the manufacturers liable anyway. ${ }^{55}$

Ophiolite Complexes,” (Geological Society of America, Special paper 373, 2003) http://specialpapers.gsapubs.org/content/373/447.abstract.

${ }^{51}$ In re Joint Eastern \& Southern Dist. Asbestos Lit., 129 BR 710 - Dist. Court 1991, at 737.

52 Asbestos.com, "New York Mesothelioma and Asbestos Exposure Risks," September 30, 2009, http://www.asbestos.com/states/new-york/.

53 It seems the term was coined by Oliver in 1925, not Cooke in 1927, contrary to the common belief. See P. W. J. Bartrip, “Review: History of Asbestos Related Disease,” Postgraduate Medical Journal, 80 (2004) 72-76.

${ }^{54}$ Caroll (2005: xxv-xxvii, 6, 70-71, 79, 109ch. 5) (73 bankrupt firms); White (2003: 2) (600,000 claimants).

55 See William L. Prosser, "The Assault upon the Citadel (Strict Liability to the Consumer) ,'” Yale Law Journal, 69 (1960) 1099-xxx; "The Fall of the Citadel (Strict Liability to the Consumer)," Minnesota Law Review, 50 (1966) 791-xxx.. Although only in the United States has asbestos litigation become a major business, the possibility has existed in other countries too. In Japan, the Osaka District Court let plaintiffs recover against the national government, on the theory that the government caused the injury by not regulating asbestos more expeditiously. See "Sekimen higai de kuni ni baisho meirei [Compensation Order to Country for Asbestos Damages],”47 News, May 19, 2010. For a comparison of 
Another problem was Scruggs's "magic" jurisdictions. Often the plaintiff can choose the forum in which to litigate. Because large corporations operate over the entire U.S., they have close enough contact with each state to subject them constitutionally to jurisdiction anywhere. Federalism plus product liability plus class actions makes for a poisonous mixture.

A sensible legal system would limit venue shopping. U.S. state and federal law does not. Instead, Mississippi can enforce a joinder rule under which an attorney can "file a single case that involves a Mississippi resident suing an out-of-state defendant and then join thousands of out-of-state claims to the original case. ${ }^{56}$

Attorneys for asbestos plaintiffs migrated to the jurisdictions offering the most magic. As of the mid 1990s, three counties in Texas accounted for a quarter of all new state-court suits. Within a few years, two Mississippi counties joined them. From 1998 to 2000, plaintiffs filed nearly 20,000 asbestos cases (10 percent of the total) in those two Mississippi counties. ${ }^{57}$ In Jefferson County, Mississippi, (pop. 9,740), 73 mass-action lawsuits representing more than 3,000 plaintiffs were filed in $2000 .^{58}$ _As of 1995, just ten law firms represented three-quarters of all new asbestos suits. ${ }^{59}$ Economist Michelle White estimates that by trying a case in one of the magic jurisdictions a plaintiff increased his judgment by 1.7 to 2.6 million dollars, ${ }^{60}$

3. Litigation. -- (a) The Stakes. In part, Scruggs won the settlements he did by raising the stakes against the defendants. As in securities class actions, the asbestos bar extracted settlements by threatening overwhelming liability. The RAND Corporation estimates that from 1993 to 2001 the 730,000 plaintiffs litigated only 526 trials. The lawyers selected cases they could win to go to trial to provide public examples they could point to for private settlements. Of the cases that went to trial, they won 64 percent with mean damages of $\$ 812,000$ in the wins, and punitive damages averaging 1.4 million dollars in the 17 percent of cases that awarded them. ${ }^{61}$

The plaintiff's bar pushed clients with mesothelioma and other serious injuries to trial and used the threat of that litigation to settle the rest of their cases. In 2002, for instance, plaintiffs asserted 1,856 mesothelioma claims and 50,112 claims involving no malignancy, many of which involved no impairment at all. ${ }^{62}$

various countries, see Nicholas Roenneberg, Asbestos: Anatomy of a Mass Tort, Munich Re, http://www.munichre.com/publications/302-06142_en.pdf.

56 Michelle J. White, "Understanding the Asbestos Crisis," Unpub'd, May 2003, http://www.law.yale.edu/documents/pdf/white.pdf.

57 Stephen J. Carroll, et al., Asbestos Litigation 63 (Santa Monica: Rand, 2005).

${ }^{58}$ Peter Boyer, The Bribe, The New Yorker, May 19, 2008.

${ }^{59}$ Carroll, supra note, at 24.

${ }^{60}$ White (2003), supra note, at 3.

${ }^{61}$ Carroll, supra note, at xxii, 35, 49-53; White (2003), supra note, at 13.

${ }^{62}$ Carroll, supra note, at 49-53, 72, 76. 
On behalf of his asbestos clients, Scruggs recovered \$300 million. For himself, he collected another $\$ 25$ million. ${ }^{63}$ Recalling our earlier figures, note that he indeed was the most efficient processor of asbestos litigation, a very good deal for his clients.

(b) Expert witnesses. In 2008, The Wall Street Journal reported that one doctor had diagnosed over 7,300 individual claimants with asbestos-related diseases. ${ }^{64}$

Defendants presented evidence that Dr. Kelly was neither a radiologist nor a pulmonologist and had failed the test that certifies doctors to read X-rays for lung disease. They also showed that the overwhelming majority of hospital radiologists who had reviewed Dr. Kelly's patients found no evidence of disease. An outside panel of radiologists who looked at Dr. Kelley's work found abnormalities in only 6 of 68 patients; Dr. Kelley had found abnormalities in 60 of those 68 .

For each diagnosis, the plaintiffs' lawyers paid Kelly \$500.

In 2005, Texas federal judge Janis Jack uncovered a bigger scam still. Presiding over silicosis suits, ${ }^{65}$ she noticed a sudden and massive increase in silicosis claims, but diagnosed by a remarkably small number of doctors.

Twelve doctors diagnosed all 9,083 Plaintiffs. This small cadre of nontreating physicians, financially beholden to lawyers and screening companies rather than to patients, managed to notice a disease missed by approximately 8,000 other physicians -- most of whom had the significant advantage of speaking to, examining, and treating the Plaintiffs. (398 F. Supp. 2d at 633)

The increase coincided with the shift in focus at several law firms from asbestosis to silicosis. Silicosis and asbestosis look very different in an X-ray and a patient almost never has both diseases (398 F. Supp. 2d at 595). Curiously, Judge Jack's plaintiffs arrived with both diseases:

When Dr. Harron first examined 1,807 Plaintiffs' X-rays for asbestos litigation (virtually all done prior to 2000, when mass silica litigation was just a gleam in a lawyer's eye), he found them all to be consistent only with asbestosis and not with silicosis. But upon re-examining these 1,807 MDL Plaintiffs' X-rays for silica litigation, Dr. Harron found evidence of silicosis in every case. (398 F. Supp. 2d at 607)

Judge Jack concluded that all but one of the 10,000 or so cases were fraudulent. Were the attorneys foolish to have brought them to court? She did impose a $\$ 8,250$ fine on the worst-offending law firm, saying that "The Court trusts that this relatively minor sanction will nonetheless be sufficient to serve notice to counsel that truth matters in a courtroom no less than in a doctor's office." Perhaps the shame of it overwhelmed the reprimanded lawyers, but most of us would draw the exact opposite conclusion about

\footnotetext{
63 Who's Afraid of Dickie Scruggs?, Newsweek, Dec. 5, 1999, www.newsweek.com/1999/12/05/who-s-afraid-of-dickie-scruggs.html.

64 “Colombo the Asbestos Sleuth," Wall Street Journal, Dec. 23, 2008, http://online.wsj.com/article/SB122999900768229123.html. “Michigan Malpractice,” Wall Street Journal, Nov. 10, 2008, http://online.wsj.com/article/SB122628156208212443.html.

${ }^{65}$ In re Silica Products Liability Litigation, 398 F. Supp. 2d 563 (S.D. Tex. 2005); see The Silicosis (2009).
} 
truth in courtrooms. In any case, despite Judge Jack's contempt for the claims, she remanded all but the lone meritorious one to state courts--- in Texas and Mississippi. ${ }^{66}$

(c) Prosecution. After hurricane Katrina became news, Scruggs turned to State Farm Insurance. The insurer had unfairly denied claims brought by Gulf Coast residents, he argued. On behalf of 640 clients, He negotiated $\$ 80$ million in settlements for 640 clients and \$26.5 million for the attorneys.

How Scruggs induced State Farm to pay illustrates the tie between litigation and politics. In this case, the method was to buy an attorney general, use him to threaten criminal charges against your civil defendant, and get the charge dropped if the defendant pays up. Scruggs was a major benefactor of Mississippi Attorney General Jim Hood. In the 40 days before one election, Scruggs, a close associate, and two lawyers gave $\$ 472,000$ to the Democratic Attorneys General Association, which then gave $\$ 550,000$ to Hood's campaign. ${ }^{67}$ State Farm faced a simultaneous civil suit from Scruggs and criminal investigation from Hood. Hood's deputy insurance commissioner recalled Hood's saying that if, "they don't settle with us, I'm going to indict them all, from [State Farm CEO] Ed Rust down." But State Farm settled and the criminal investigation was closed. ${ }^{68}$

Of course, American law is not infinitely malleable, and Scruggs did go one step too far. With the enormous fees at stake, Scruggs and his fellow attorneys fell into bitter disputes. To obtain a ruling in his favor against a co-counsel in the Katrina litigation, Scruggs offered a judge a mere $\$ 50,000$. The judge went to the FBI, the U.S. Attorney prosecuted Scruggs, and in 2008 he was sentenced to five years in prison.

\section{Implications}

From coffee spills to securities class actions to asbestos experts to tobacco settlements, American courts have made a name for themselves as a wild lottery with a big payout for a lucky few specialist lawyers. At least in part, however, the reputation is unfounded. American judges seem to handle routine contract and tort disputes as well as their peers in other wealthy countries. Americans do not file an unusually high number of law suits. They do not employ large numbers of judges or lawyers. They do not pay more to enforce contracts. And they do not pay unusually high prices for insurance against routine torts.

Rather, American courts have ruined their good name by mishandling a few special aspects of law. In this article we used securities actions and mass torts as illustrations, but anyone who reads a newspaper could suggest alternatives. The implications for reform are straightforward: focus not on litigation as a whole; but on areas of law where America is unique.

${ }^{66}$ RAND Issues Report on Abuse of Medical Diagnostic Practices in Mass Litigation,

By Mark A. Behrens \& Corey Schaecher, Engage, October 2009, 10: 108-111, http://www.shb.com/attorneys/Behrens/RANDReport_2010.pdf.

67 Roger Parloff, "The Siege of State Farm," (2008), http://money.cnn.com/2008/04/09/news/newsmakers/parloff_scruggs.fortune/index/htm.

${ }^{68}$ Parloff, 2008. Alan Lange, “Anatomy of a Shakedown: Dickie Scruggs' Mighty Fall. Y'all,” Politics, Dec. 24, 2008. www.yallpolitics.com/index.php/yp/post/13431/. 